\title{
Heterozygous Beta Chain Variant Hemoglobin Pusan: A Rare Case Report in Turkish Population
}

\author{
Heterozigot Beta Zincir Varyantı Hemoglobin Pusan: \\ Türk Toplumunda Nadir Bir Olgu Sunumu
}

\section{Durmus AYAN $\odot$, Ozgur KIRBIYIK $\odot$, Berk OZYILMAZ $\odot$}

Ethics Committee Aproval: Not Applicable.

Confillict of Interest: The authors declare that they have no conflict of interest.

Funding: None.

Informed Concent: Informed consent was taken.
Cite as: Ayan D, Kirbiyik O, Ozyilmaz B. Heterozygous beta chain variant hemoglobin Pusan: A rare case report in Turkish population. Medeniyet Med J. 2019;34:396-9.

\begin{abstract}
The case, detected during routine thalassemia (hemoglobin variant) screening, was a 25-yearold male patient of Turkish origin. Physical examination revealed no abnormal findings. Laboratory findings did not reveal any signs of anemia (iron deficiency, B12 deficiency, etc.). However, when the hemoglobin variant report was being evaluated, it was found that besides the normal hemoglobin peaks, there was another peak that had not been defined before. The sample was sent to genetic analysis for verification with the suspicion of an unknown hemoglobin variant. According to the genetic analysis, the unknown hemoglobin variant was found to be Hemoglobin Pusan (Hb Pusan). The aim of this study is to give information about a hemoglobin variant which is rarely seen in Turkish population and to raise awareness about this hemoglobin variant. In addition, clinical and hematological findings of this disease are discussed in the case report.
\end{abstract}

Keywords: Thalassemia, hemoglobin Pusan, thalassemia-like diseases, hemoglobin disorders

Öz

Rutin talasemi (hemoglobin varyant) taraması esnasında tespit edilen vaka 25 yaşında erkek hasta ve Türk kökenlidir. Fizik muayenesinde herhangi bir anormal bulguya rastlanmadı. Laboratuvar incelemesinde anemi yönünden herhangi bir bulguya (demir eksikliği, B12 eksikliği vs.) rastlanmadı. Ancak hemoglobin varyant raporu değerlendirilirken, normal hemoglobin piklerinin yanı sıra daha önce tanımlanmayan bir pik daha olduğu tespit edildi. Numune bilinmeyen bir hemoglobin varyantı șüphesi ile doğrulama yapılması için genetik analize gönderildi. Genetik analiz sonucuna göre bilinmeyen hemoglobin varyantının Hemoglobin Pusan (Hb Pusan) olduğu tespit edildi. Bu çalışmanın amacı Türk toplumunda nadir görülen bir hemoglobin varyantı hakkında bilgilendirme yaparak, bu hemoglobin varyantı hakkında farkındalığı arttırmaktır. Ayrıca bu hastalığın klinik ve hematolojik bulguları vaka raporunda tartışılmıştır.

Anahtar kelimeler: Talasemi, hemoglobin Pusan, talasemi benzeri hastalıklar, hemoglobin bozuklukları
Received: 7 September 2019

Accepted: 23 October 2019

Online First: 26 December 2019

Corresponding Author: D. Ayan

ORCID: 0000-0003-2615-8474

Amasya University, Sabuncuoğlu Şerefeddin Training and Research Hospital, Department of Medical Biochemistry, Amasya, Turkey

durmus.ayan@gazi.edu.tr

\section{O. Kirbiyik}

ORCID: 0000-0003-1333-2007 Izmir Tepecik Training and Research Hospital,

Department of Medical Genetic, Izmir, Turkey

B. Ozyilmaz

ORCID: 0000-0003-2654-3698 Izmir Tepecik Training and Research Hospital,

Department of Medical Genetic, Izmir, Turkey 


\section{INTRODUCTION}

Hemoglobinopathy is a genetic disorder that causes an abnormal structure in the globin chain of the hemoglobin molecule ${ }^{1}$. Thalassemia occurred when the globin chain(s) of hemoglobin which is defined as $\alpha, \beta, \gamma$, or $\delta$, has been formed at low levels or has not been formed at all ${ }^{1,2}$. Mutations in the beta-globin chain are quite common ${ }^{3}$. Hemoglobinopathies can be both heterozygous and homozygous ${ }^{3}$. The most common hemoglobinopathy in Turkish population is Hemoglobin S (HbS, $\beta 6 \mathrm{Glu}-\mathrm{Val}$ ) which is followed by Hemoglobin D $(\beta 121 \mathrm{Glu} \rightarrow \mathrm{Gln})^{4,5}$. Hemoglobin Pusan (Hb Pusan) is a heterozygote and a rare hemoglobin variant type which was previously revealed in Korean society, that is identified by the substitution of histidine which is found in the $146^{\text {th }}$ amino acid residue of the beta globulin chain for asparagine amino acid (CAC>GAC or His $>$ Asn) ${ }^{2}$.

\section{CASE REPORT}

A 25-year-old male patient of Turkish origin was admitted to the University Hospital for thalassemia screening. Physical examination findings of the patient revealed no signs of anemia or other diseases. Liver function tests (aspartate aminotransferase (AST), alanine aminotransferase (ALT), total bilirubin and direct bilirubin levels), iron, total iron-binding, B12, and folic acid levels were normal. Serology tests were negative. He was not a smoker. In the hematology panel, hemoglobin $(\mathrm{Hb})$ was $17 \mathrm{~g} / \mathrm{dL}$ (reference range, 13.2-16.6), red blood cell (RBC) count was 5.95 $\times 10^{12} / \mathrm{L}$ (reference range, 3.8-5.1), white blood cell $\left(\mathrm{WBC}\right.$ ) count was $6.21 \times 10^{12} / \mathrm{L}$ (reference range, 4.5-10.5), mean corpuscular volume (MCV) was $84.5 \mathrm{fL}$ (reference range, 80-102), and mean corpuscular hemoglobin $(\mathrm{MCH})$ was 28.6 pg (reference range, 25.6-34). Hb value and RBC count are above the normal $\left(17 \mathrm{~g} / \mathrm{dL}\right.$ and $\left.5.95 \times 10^{12} / \mathrm{L}\right)$ therefore, there is some degree of erythrocytosis in this case and measured P50 value by using oxymeter was low $(20 \mathrm{mmHg}$ ) than normal control (26.5 $\mathrm{mmHg}$, reference range $26 \pm 1.3$ $\mathrm{mmHg}$ ). In thalassemia analysis examined with high-performance liquid chromatography (HPLC) method, an abnormal unidentified hemoglobin peak (RRT: 1.67 min., \%46.9) was detected apart from the identified two basic hemoglobin peaks, which are HbAO (RRT: 1.00 min., 42.6\%) and HbA2 (RRT: 0.88 min., 2.4\%), which were defined according to relative retention time (RRT) per minute. When the same sample was examined with Cation exchange HPLC method in a different system, another suspected abnormal hemoglobin peak (RT: $1.68 \mathrm{~min} ., 48.3 \%$ ), was detected apart from two basic hemoglobin peaks, which are $\mathrm{HbAO}$ (RT: 2.57 min., 39.0\%) and HbA2 (RT: 3.73 min., 2.4\%) This unknown hemoglobin variant was sent to genetic analysis (DNA chain analysis) for verification. In the DNA sample obtained from the patient's peripheral blood, HBB gene (GRChg37: NM_000518) sequence analysis (5'UTR (-110), exon 1-3, IVS1-2, 3'UTR)) was performed and heterozygous $\mathrm{Hb}$ Pusan variant was detected as HBB: c.439C> A (p. His147Asn). Written informed consent was obtained from the patient for the publication of the case report and the accompanying images.

\section{DISCUSSION}

This present study examined the clinical features and laboratory findings of a heterozygous hemoglobin variant, which which was defined in the beta globulin chain and which is rare in the Turkish population. Hemoglobin variant detected during routine laboratory evulation was determined as heterozygous $\mathrm{Hb}$ Pusan according to genetic analysis results. Physical examination and laboratory results of the case have revealed no findings of anemia. There are no publications or case reports in the literature indicating that this variant type, which was previously revealed in a Korean society, was detected in a patient of Turkish origin. In this respect, the present study is the first of its kind. 
Hb Pusan is a type of a hemoglobin variant caused by the substitution of histidine, which is found in the $146^{\text {th }}$ amino acid residue of the beta globulin chain, for asparagine amino acid (p.His147Asn, HBB: $c .439 C>A)^{2}$. The genomic DNA of the sample was isolated according to the manufacturer's protocols. For the Sanger sequencing of HBB gene, the Polymerase chain reaction (PCR), purification (ExoSAP-IT®, Affymetrix) and cycle sequencing PCR (BigDye ${ }^{\circledR}$ Terminator v3.1, Thermo Scientific) reactions were carried out. Products were purified (ZR DNA Sequencing Clean-up Kit TM, Zymo Research) and run by capillary electrophoresis (3500 Genetic Analyzer, Thermo Scientific). The DNA sequences obtained were analysed in the Sequencing Analysis Program and compared with the reference sequences. DNA sequencing with this method is used to detect genetic mutation of hemoglobin variants that cannot be detected by the methods such as HPLC and Cation exchange high performance liquid chromatography ${ }^{6,7}$. Hb Pusan had close retention times in both boronate affinity HPLC method (RT:1.67 min.) used at Trinity Biotech Primus Ultra 2 hemoglobin variant analyzer and in cation exchange HPLC method (RT:1.68 min.) used at Bio-Rad Variant Turbo II hemoglobin variant analyzer. Both the boronate affinity HPLC method and the cation exchange HPLC method, provide high precision and accuracy for hemoglobin variant analysis. Furthermore they provide high accuracy measurements in thalassemia cases where HbA2 level is very important ${ }^{8}$. Genetic mutations that have been encountered in the same region as $\mathrm{Hb}$ Pusan, and that have previously been identified by the DNA chain analysis, are as follows: Hemoglobin Hiroshima (CAC>GAC, $\beta 146$ histidine $\rightarrow$ aspartic acid), Hemoglobin Bologna (CAC>TAC, $\beta 146$ histidine $\rightarrow$ Tyrosine, HBB: c.439 $\mathrm{C}>\mathrm{T}$ ), Hemoglobin York (CAC>CCC, $\beta 146$ histidine $\rightarrow$ Proline, HBB: c.440 A $>C$ ), Hemoglobin Cochin-Port Royal (CAC>CGC $\beta 146$ histidine $\rightarrow$ Arginine, HBB: c.440 A>G), Hemoglobin Cowntown (CAC>CTC, $\beta 146$ histidine $\rightarrow$ Leucine, HBB: c.440 A>T), Hemoglobin Kadaria I (CAC>CAA, $\beta 146$ histidine $\rightarrow$ Glycine, HBB: c.441 C>A), and
Hemoglobin Kadaria II (CAC>CAG, $\beta 146$ histidine $\rightarrow$ Glycine HBB: c.441 C>G) $)^{9-15}$. Furthermore, all the variants of the position 146 display a mild increased oxygen affinity leading to some degree of erythrocytosis ${ }^{9-15}$ and apparently this seems to be the case of the carrier of $\mathrm{Hb}$ Pusan since the measured $\mathrm{Hb}$ value and $\mathrm{RBC}$ count are above the normal $(17 \mathrm{~g} / \mathrm{dL}$ (reference range: 13.2-16.6 $\mathrm{g} / \mathrm{dL}$ ) and $5.95 \times 10^{12} / \mathrm{L}$ (reference range: 3.8-5 $\left.\left..1 \times 10^{12} / \mathrm{L}\right)\right)$. Additionally, measured P50 value was low $(20 \mathrm{mmHg}$ ) than normal control (26.5 $\mathrm{mmHg}$, reference range $26 \pm 1.3 \mathrm{mmHg}$ ) due to mild oxygen affinity.

The clinical features and genetic mutations of many hemoglobin variants have not yet been clarified. As discussed above, there are too many hemoglobin variant types that appear even in the same gene region. Different clinical and hematological features can be seen in different hemoglobin variant types while different clinical and hematological features can also be seen in a single hemoglobin variant. Therefore, different clinical and hematological features of the hemoglobin variant, detected in the present study, can be revealed in future studies. We believe that our case study will enlighten the upcoming regional or racial studies.

\section{Limitations}

Although the present case report was well constructed, there were some limitations. Firstly, due to the lack of data on $\mathrm{Hb}$ Pusan case, different hematological conditions and physical examination findings in the same case could not be discussed. Secondly, family investigations which belong to this case could not be carried out because other family members did not allow testing.

\section{REFERENCES}

1. Taher AT, Weatherall DJ, Cappellini MD. Thalassaemia. Lancet. 2018;391:155-67. [CrossRef]

2. Yun YM, Ji M, Ko DH, et al. Hb variants in Korea: effect on HbA1c using five routine methods. Clin Chem Lab Med. 
2017;55:1234-42. [CrossRef]

3. Sabath DE. Molecular Diagnosis of Thalassemias and Hemoglobinopathies: An ACLPS Critical Review. Am J Clin Pathol. 2017;148:6-15. [CrossRef]

4. Canatan D. Thalassemias and hemoglobinopathies in Turkey. Hemoglobin. 2014;38:305-7. [CrossRef]

5. Akar N. An updated review of abnormal hemoglobins in the Turkish population. Tur J Hematol. 2014;31:97-8. [CrossRef]

6. Wajcman H, Moradkhani K. Abnormal haemoglobins: detection \& characterization. Indian J Med Res. 2011;134:538.

7. Murthy S, Benavides R. A rare hemoglobin variant, $\mathrm{Hb}$ Belliard. Proceedings. 2017;30:184-5. [CrossRef]

8. Keren DF, Shalhoub R, Gulbranson R, et al. Expression of hemoglobin variant migration by capillary electrophoresis relative to hemoglobin A2 improves precision. Am J Clin Pathol. 2012;137:660-4. [CrossRef]

9. Harano T, Harano K, Kushida Y, et al. [beta 146(HC3)His---Gln]: a new beta chain variant with an amino acid substitution at the C-terminus. Hemoglobin. 1992;16:85-91. [CrossRef]

10. Perutz MF, Fermi G, Shih TB. Structure of deoxyhemoglobin Cowtown [His HC3(146) beta----Leu]: origin of the alkaline Bohr effect and electrostatic interactions in hemoglobin. Proc. Natl. Acad. Sci U S A.1984;81:4781-4. [CrossRef]

11. Russu IM, Ho C. Assessment of role of beta 146-histidyl and other histidyl residues in the Bohr effect of human normal adult hemoglobin. Biochem. 1986;25:1706-16. [CrossRef]

12. Bare GH, Bromberg PA, Alben JO, et al. Altered C-terminal salt bridges in haemoglobin York cause high oxygen affinity. Nature. 1976;259:155-6. [CrossRef]

13. Ivaldi G, David O, Paradossi V, et al. Hb Bologna-St. Orsola [beta146(HC3)His-->Tyr]: a new high oxygen affinity variant with halved Bohr effect and highly reduced reactivity towards 2,3-diphosphoglycerate. Hemoglobin. 1999;23:353-9. [CrossRef]

14. Imai K. Oxygen-equilibrium characteristics of abnormal hemoglobin Hiroshima (alpha-2 beta-2 143 Asp). Arch Biochem Biophys. 1968;127:543-7. [CrossRef]

15. Hamilton HB, luchi I, Miyaji T, et al. Hemoglobin Hiroshima (beta-143 histidine--aspartic acid): a newly identified fast moving beta chain variant associated with increased oxygen affinity and compensatory erythremia. J Clin Invest. 1969;48:525-35. [CrossRef] 